\title{
Factors Affecting Academic Achievement of Secondary School Students in
} Mauritius

\author{
Shakeel Mohammad Cassam Atchia ${ }^{1 *}$ and Vinayagum Chinapah ${ }^{2}$ \\ ${ }^{1}$ Mauritius Institute of Education, Réduit, Mauritius \\ ${ }^{2}$ International and Comparative Education, Stockholm University, Stockholm, Sweden
}

\begin{abstract}
This paper analyses the contextualised determinants affecting the academic achievement of secondary school students in Mauritius. A mixed methodology was used to understand the effect of the determinants on students' achievement considering the academic progression of learners from one point (CPE: Examination marking the end of primary schooling) to another (NG9A: Checkpoint assessment after three years of secondary schooling). The first phase had a nonpositivist epistemological stand using the qualitative method of 'focus group discussion' to identify the determinants and then validate the TIMSS questionnaire. The second phase had a post-positivist epistemological stand where an amended version of the standardised international questionnaire TIMSS was administered to collect data from a sample of 600 students. The primary data were analysed to produce a Linear Multiple Regression Model. The findings reveal that $90.1 \%$ achievement can be explained by the variables of school leadership, student, socioeconomic factor, and teacher $(\mathrm{R}$ square $=0.9 .1 ; \mathrm{p}<0.05)$. The model shows that school leadership has a higher positive correlation on $(\beta=0.419)$ students' achievement followed by student factor $(\beta=0.227)$, tuition teacher $(\beta=0.154)$, school teacher $(\beta=0.117)$ and socioeconomic status $(\beta=0.048)$.
\end{abstract}

Keywords: TIMSS; Determinants; Academic achievement; Value-added; Multiple linear regression model

* Corresponding Author. Shakeel.Atchia@mie.ac.mu
ISSN: 2091-0118 (Print) / 2091-2560 (Online)

(C) 2019 The Author(s).

Journal homepages: ${ }^{1}$ http://www.kusoed.edu.np/journal/index.php/je

${ }^{2}$ https://www.nepjol.info/index.php/JER/index 
Factors Affecting Academic Achievement | 71

\section{Introduction}

During the past decades, there have been major changes in the Mauritian education system with the prime objective of providing high-quality education. The most recent education reform is being implemented and is termed 'Nine Years of Continuous Basic Education (NYCBE)' whose provision is in line with the international commitment to the UN Sustainable Development Goals, more specifically, Goal 4 (SDG4) on Education. The latter ensures 'inclusive and equitable quality education and promotes lifelong learning opportunities for all'. Thus, the educational reform, in its quest to provide inclusive and equitable quality education to every Mauritian child, needs to address the actual challenges facing our education system such as the low academic performance of the students leading to the increasing achievement gap and high rate of drop-out.

The paper aims to provide ground data to all stakeholders on the factors that affect the academic achievement of Mauritian students at the secondary school level. It, therefore, addresses an important, much relevant and contextual educational policy domain on the improvement of the quality of education being offered in Mauritius and inform future educational reforms in Mauritius.

The objectives of the study are:

i) To identify the main factors affecting students' academic achievement at the secondary school level, in Mauritius.

ii) To determine and analyse the academic achievement of students at the lower secondary level as measured by 'value-added score'.

iii) To explore the impacts of the identified factors on the academic achievement of secondary school students through a Multiple Linear Regression model.

\section{Theoretical Framework}

The theoretical framework used in this study is the General Systems theory developed by Ludwig Von Bertalanffy in 1956. The theory is adapted to the objectives of the study as it does not focus only on the input (determinants) and output (students' achievement) mechanism, but on the relations and interactions between the different parts, whose amalgamated effects, affect the achievements of students. Actually, Carr (2006), Capra (1996), Yaşar (2017), and Chikere and Nwoka (2015) stated that the 
72 | S. M. C. Atchia \& V. Chinapah

general systems theory focuses on the arrangement of and relations between the parts and how they work together as a whole, which is often referred to as a holistic approach to understanding phenomena.

Many researchers have used the general systems theoretical framework to produce contextualized conceptual frameworks of factors affecting students' academic achievement. However, the factors vary from person to person and country to country (Mushtaq \& Khan, 2012).

\section{Common Factors Affecting Students' Academic Achievement}

This section describes the relevant factors that commonly affect the academic achievements of students in line with the above-mentioned theoretical framework.

Socioeconomic factors. Socioeconomic factor (SEF) is one of the most researched factors contributing to the academic achievements of students. In fact, Mirowsky (2017), Benner, Boyle, and Sadler (2016), Berkowitz, Moore, Avi Astor, and Benbenishty (2017), and Hair, Hanson, Wolfe and Pollak (2015) revealed a significant effect of SEF on students' achievement. Some researchers concluded that students with high socioeconomic status perform better than those with low socioeconomic status (Kahlenberg, 2006; Kirkup, 2008). However, researchers such as Pedrosa, Dachs, Maia, and Andrade (2006) found that students coming from disadvantaged socioeconomic and educational homes perform relatively better than those coming from higher socioeconomic and educational strata. They called this phenomenal educational resilience.

School leadership. There is a growing consensus, based on empirical evidence, that positive influence of successful leadership can have a positive effect on school performance and students' learning achievement (Allen, Grigsby, \& Peters, 2015; Beare, Caldwell, \& Millikan, 2018; Day, Gu, \& Sammons, 2016; Hitt \& Tucker, 2016; Leithwood, Harris, \& Hopkins, 2008; Pont, Nusche, \& Moorman, 2008). Actually, it is revealed that school leaders can improve students' achievement in different ways varying from (i) direct and indirect effect on teaching and learning (ii) involving different stakeholders (such as parents) in school and (iii) providing a proper ethos and climate (Mulford et al., 2009; Supovitz, Sirinides, \& May, 2009), which eventually impact students' achievement.

Journal of Education and Research, Vol. 9, No. 1, 2019 
Student factor. As the main stakeholders, students have a major role in their academic achievement. Indeed, researchers such as Konstantopoulos (2009), Lubienski (2002), Ma and Klinger (2000), Shores, Shannon, and Smith (2010) and Tate (1997) concluded that student factors influence students' academic achievement. Kang and Keinonen (2018), Han, R. Capraro, and M. Capraro (2015), Lemberger, Selig, Bowers, and Rogers (2015) explained that students' time management, self-motivation, engagement, behaviour and attitudes are the key factors governing their academic success.

Teacher factor. Many studies have provided empirical evidence of the positive correlation between teacher factor and students' achievements. For instance, Vizeshfar and Torabizadeh (2018), and Adnot, Dee, Katz, Wyckoff, and Katz (2016) showed than an effective teacher can dramatically alter students' educational and thus economic outcomes. In fact, analysis of the literature revealed that that the impact of educators on students' life and achievement vary widely from being a guide, a facilitator, a model, a pedagogical leader, a source of knowledge to being a friend and a confider.

Private tuition. Another factor, which works in parallel to school, is the private tuition. Private supplementary tutoring is not per se a new phenomenon, but it takes different forms in different cultures (Bray, 2009). Some aspects of private tutoring may be considered positive. Tutoring creates constructive out-of-school activities for young people and thus students who receive private tuition are likely to perform better in school and to stay in the education system for longer durations (Bray, 2010). However, tutoring may also distort parts of the mainstream system, place an economic burden on households, and create excessive pressure for children and adolescents. Among the most problematic aspects are cases in which private tutoring becomes a substitute for the mainstream. Especially near the time of major external examinations, schools in some countries may be perceived by pupils to be less able to cater for their specific needs (Bray, 2010), and thus they increasingly rely on private tutoring.

\section{Methodology}

A general mixed methodology consisting of two phases was used to study the factors affecting students' academic achievement. Figure 1 below summarises the stepwise procedure of the study. 


\section{Phase 1:}

Step 1: Implementation of Focus group discussions

Step 2: Analysis of transcripts to identify the different factors affecting students' achievements in Mauritius.

\section{Phase 2:}

Step 1: Selection of standardized data collection instrument (questionnaire).

Step 2: Modification of the instrument based on information gathered in phase 1

Step 3: Pilotting and finalisisng the instrument on 50 respondents

\section{Phase 2:}

Step 4: Sampling

-Calculate sample size using stratified sampling technique

-Selection of respondents

\section{Phase 2:}

Step 5: Data collection (Implementation of questionnaire)

Step 6: Data Analysis I

- Calculate the 'value added score' of each respondent as a measure of achievement.

Step 7: Data Analysis II using SPSS

Derivation of a Multiple Linear regression model (MLRM)' showing the relative impact of each factor on students' achievement

Figure 1. Stepwise research design.

The first phase had a non-positivist epistemological stand using the qualitative method of 'focus group discussion' (FGD) to (i) identify factors affecting students' achievement, and (ii) to collect information for amending the 'Trends in International Mathematics and Science Study (TIMSS)' student's questionnaire so that it fits the Mauritian context. The focus groups included students, school administratives such as 
rectors, deputy rectors and senior educators, quality assurance officers, educators and parents.

The second phase had a post-positivist epistemological stand with a quantitative approach. A sample of 600 participants, representative of the Mauritian student population, was selected using a stratified sampling method taking into consideration the students' gender, type of schools (National and Regional) and educational zones (Mauritius is divided into four educational zones), for the implementation of the amended version of the TIMSS student's questionnaire.

The data were analysed using the SPSS version 21 to: (i) calculate the value-added score, that is, the academic achievement of each respondent, and (ii) model the impacts of the identified factors on students' academic achievement through a 'Multiple Linear Regression Model' (MLRM).

\section{Value Added Score}

The Value Added Score (VAS) of each student was calculated as follows:

Value-added score $=$ Average point score $($ APS $)$ at NG9A - Average point score at C.P.E, where: APS for each student = (Point in English + Point in Mathe matics $) / 2$

NG9A: National Grade 9 Assessment (Checkpoint assessment after three years of secondary schooling)

CPE: Certificate of Primary Education (Examination marking the end of primary schooling)

The decision of using only English and Mathematics to calculate the Average Point Score (APS) was based on the following:

- The value-added score should be in line with the Mauritian Ministry's Policy on numeracy and literacy,

- VAS required considering examinable subjects common at both CPE and NG9A for a fair comparison, and

- Common subjects used by other researchers in the literature. 
76 | S. M. C. Atchia \& V. Chinapah

\section{Multiple Linear Regression Model}

After data inputs in SPSS were completed, categorical variables were checked and output of descriptive statistics analysed to identify errors. Then data was cleaned, and the negatively worded items were reversed by transforming and recoding into the same variables.

Once the data file was checked for accuracy, the reliability of the items was tested using the reliability estimates. The assumptions for multiple linear regression equation, that is, Linearity, Normality, Multicollinearity, Autocorrelation and Homoscedasticity were then tested before running the MLRM. The model will explain the strength of the different variables on the achievement of students.

\section{Results}

The findings of this study are presented in two phases.

\section{A: Phase I}

The first phase was dedicated to exploring the factors affecting the academic achievement of students in the Mauritian context. The data (transcripts) collected from the FGDs were coded and analysed manually using the long-table method. The categories and over-arching ideas emerged from the analysis, as shown in table 1, led to the identification of socio-economic factors, student factors, school leadership and teacher factors at school and private tuition levels as the main factors affecting the academic achievement of secondary school students.

Table 1 presents the percentage of participants highlighting the specific factors that are considered as determinants of students' academic achievements. It also presents their views on how each factor affects students' achievement.

Journal of Education and Research, Vol. 9, No. 1, 2019 
Table 1

Views of Participants in the FGD

\begin{tabular}{|c|c|c|c|c|c|}
\hline \multirow[t]{2}{*}{$\begin{array}{l}\text { Overarching } \\
\text { ideas emerged } \\
\text { during the FGD }\end{array}$} & \multicolumn{4}{|c|}{$\begin{array}{l}\text { Percentage of participants } \\
\text { highlighting the specific } \\
\text { factor during the FGD } \% \%\end{array}$} & \multirow{2}{*}{$\begin{array}{l}\text { Vie ws of participants on how the specific } \\
\text { factor affect students' achievement at } \\
\text { the secondary level in Mauritius }\end{array}$} \\
\hline & 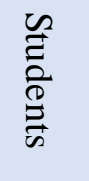 & 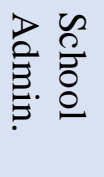 & 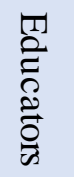 & 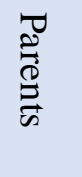 & \\
\hline $\begin{array}{l}\text { Socio-Economic } \\
\text { Factor }(\mathrm{SEF})\end{array}$ & 100 & 83 & 100 & 83 & $\begin{array}{l}\text { Most participants highlighted that one of } \\
\text { the main factors affecting students' } \\
\text { achievement in Mauritius is SEF. } \\
\text { They explained that SEF plays a crucial } \\
\text { role in students' achievement through } \\
\text { parents' education level, marital status, } \\
\text { financial status, guidance, support and } \\
\text { involvement; peer influence; social } \\
\text { networking; community \& environment; } \\
\text { absenteeism; cultural differences; and } \\
\text { language exposed }\end{array}$ \\
\hline $\begin{array}{l}\text { Students Factor } \\
\text { (SF) }\end{array}$ & 100 & 83 & 83 & 83 & $\begin{array}{l}\text { Most participants highlighted that one of } \\
\text { the main factors affecting students' } \\
\text { achievement in Mauritius is SF } \\
\text { They explained that SF plays a crucial role } \\
\text { in terms of time management, attitudes and } \\
\text { behaviours through use/misuse if ICT tools } \\
\text { \& Social media; commitment \& } \\
\text { engagement in learning, shirking of } \\
\text { classes, intrinsic motivation \& } \\
\text { competition; boyfriend/ girlfriend affairs; } \\
\text { stress, depression \& health problems; self- } \\
\text { esteem; CPE intake/ entry point and } \\
\text { culture. }\end{array}$ \\
\hline
\end{tabular}




\begin{tabular}{|c|c|c|c|c|c|}
\hline $\begin{array}{c}\text { Teacher Factor } \\
\text { at School le vel } \\
\text { (TFSc) }\end{array}$ & 83 & 100 & 83 & 83 & $\begin{array}{l}\text { Most participants highlighted that one of } \\
\text { the main factors affecting students' } \\
\text { achievement in Mauritius is Teacher factor } \\
\text { at school and tuition levels. } \\
\text { They explained the impact of TFSc/TFTu } \\
\text { through the quality of teaching; teacher- } \\
\text { student interaction; use of ICT in } \\
\text { teaching/learning; motivation, support, }\end{array}$ \\
\hline $\begin{array}{c}\text { Teacher Factor } \\
\text { at Tuition level } \\
\text { (TFTu) }\end{array}$ & 83 & 33 & 33 & 17 & $\begin{array}{l}\text { techniques \& strategies used in lessons; } \\
\text { classroom management; Evaluation, } \\
\text { feedback \& monitoring of students } \\
\text { achievements; content specialist; planning } \\
\& \text { organisation; the language of } \\
\text { instruction; and teacher experience \& } \\
\text { training. }\end{array}$ \\
\hline Leadership (L) & 83 & 83 & 33 & 67 & $\begin{array}{l}\text { Most participants highlighted that one of } \\
\text { the main factors affecting students' } \\
\text { achievement in Mauritius is L. } \\
\text { They explained that achievements of } \\
\text { students depend on the type of monitoring } \\
\text { done by school administration in } \\
\text { connection with educators' role in (i) } \\
\text { evaluation, feedback \& monitoring of } \\
\text { students engagement, (ii) providing quality } \\
\text { of teaching, (iii) using the appropriate } \\
\text { pedagogy, and (iv) ensuring conducive } \\
\text { ethos and climate of the school. } \\
\text { Participants also highlighted the } \\
\text { importance of community \& social } \\
\text { networking; motivation; provision of } \\
\text { needs/ resources \& opportunities to } \\
\text { students and educators; guidance \& } \\
\text { support; discipline; class size and } \\
\text { leadership styles, for students' academic } \\
\text { achievement }\end{array}$ \\
\hline
\end{tabular}




\section{B: Phase II}

The second phase was focused on modelling of the factors affecting students' achievement through the use of MLRM. The MLRM describing the cumulative impacts of the contextualised factors influencing students' academic achievements in Mauritius is as follows:

$$
\mathrm{Y}=\beta \mathrm{X} 1+\beta \mathrm{X} 2+\beta \mathrm{X3}+\beta \mathrm{X} 4+\beta \mathrm{X5}+\varepsilon(\text { constant })
$$

Achievement $=-1.559$ (constant $)+0.277$ student factor +0.048 Socio economic factor + 0.419 Leadership + 0.117 Teacher Factor (School) + 0.154 Teacher Factor (Tuition)

The MLRM shows that the identified factors have a different degree of impacts on the students' academic achievement in Mauritius. Table 2 shows that the Adjusted R square value of the model is 0.901 that is $90.1 \%$ achievement can be explained by the variables while the remaining $9.9 \%$ are describable by other factors.

Table 2

Coefficient Determination

\begin{tabular}{|c|c|c|c|c|c|}
\hline \multicolumn{7}{|c|}{ Model Summary } \\
\hline Model & R & $\begin{array}{c}\text { R } \\
\text { Square }\end{array}$ & $\begin{array}{c}\text { Adjusted R } \\
\text { Square }\end{array}$ & $\begin{array}{c}\text { Std. Error of the } \\
\text { Estimate }\end{array}$ & Durbin-Watson \\
\hline 1 & .949 & .901 & .901 & .30282 & .940 \\
\hline $\begin{array}{l}\text { Predictors: (Constant), leadership, Teacher factor Tuition, Socioeconomic Factor, Teacher } \\
\text { factor School, Student factor }\end{array}$ \\
Dependent Variable: Value-added/Achievement \\
\hline
\end{tabular}

Table 3 shows the results of the T-test where the Beta values express the relative importance of each independent variables in standardized terms. 
$80 \mid$ S. M. C. Atchia \& V. Chinapah

Table 3

Statistical Significance of the Independent Variables

\begin{tabular}{|c|c|c|c|c|c|c|c|}
\hline \multicolumn{8}{|c|}{ Coefficients } \\
\hline \multirow[t]{2}{*}{ Model } & \multicolumn{2}{|c|}{$\begin{array}{l}\text { Unstandardized } \\
\text { Coefficients }\end{array}$} & \multirow{2}{*}{$\begin{array}{c}\begin{array}{c}\text { Standar } \\
\text { dized } \\
\text { Coefficie } \\
\text { nts }\end{array} \\
\text { Beta }\end{array}$} & \multirow[t]{2}{*}{$\mathbf{t}$} & \multirow[t]{2}{*}{ Sig. } & \multicolumn{2}{|c|}{$\begin{array}{l}\text { Collinearity } \\
\text { Statis tics }\end{array}$} \\
\hline & B & $\begin{array}{l}\text { Std. } \\
\text { Error }\end{array}$ & & & & $\begin{array}{l}\text { Toler } \\
\text { ance }\end{array}$ & VIF \\
\hline (Constant) & -1.559 & .086 & & 18.136 & .000 & & \\
\hline Leadership & .032 & .002 & .419 & 15.130 & .000 & .097 & 9.287 \\
\hline Student Factor & .017 & .003 & .277 & 6.785 & .000 & .249 & 4.016 \\
\hline $\begin{array}{l}\text { Socio } \\
\text { Economic } \\
\text { Factor }\end{array}$ & .004 & .002 & .048 & 1.864 & .043 & .213 & 4.690 \\
\hline $\begin{array}{l}\text { Teacher } \\
\text { Factor (school) }\end{array}$ & .010 & .002 & .117 & 4.238 & .000 & .236 & 4.240 \\
\hline $\begin{array}{l}\text { Teacher } \\
\text { Factor } \\
\text { (Tuition }\end{array}$ & .016 & .003 & .154 & 5.738 & .000 & .212 & 4.727 \\
\hline
\end{tabular}

Tables 2 and 3 show that all the independent variables that are, Student Factors, Socio-Economic Factors, School Leadership, Teacher factor at School level and Teacher factor at tuition level are positively correlated with students' achievement at 5\% significance level. Moreover, it is noted that the factor, which influences more on students' achievement, is school leadership, followed by student factor, teacher factor at tuition level, teacher factor at school level and socio-economic factor respectively.

\section{Significance of the Model}

The MLRM is considered significant as the following assumptions are met.

- There is a linear relationship between variables

Journal of Education and Research, Vol. 9, No. 1, 2019 
- The data shows multivariate normality

- There is no or little multicollinearity

- There is no or little autocorrelation

- There is no violation of homoscedasticity

Linear relationship test. Analys is of the scatter plots and the F test value as per table 4 below reveals that the relationship between independent and dependent variables is linear.

Table 4

Relationship Between Independent and dependent Variables (F test)

\begin{tabular}{|c|c|c|c|c|c|c|}
\hline \multicolumn{2}{|r|}{ Model } & Sum of & df & $\underset{\text { Mean }}{\text { Meare }}$ & $\mathbf{F}$ & Sig. \\
\hline \multirow{3}{*}{1} & Regression & 497.690 & 5 & 99.538 & 1085.471 & .000 \\
\hline & Residual & 54.470 & 594 & .092 & & \\
\hline & Total & 552.160 & 599 & & & \\
\hline & & $\begin{array}{l}\text { Depende } \\
\text { ors: (Cons }\end{array}$ & 0 & $\begin{array}{l}\text { vement } \\
\text { SEF, T }\end{array}$ & & \\
\hline
\end{tabular}

In fact, the linear regression's F-test has the null hypothesis that there is no linear relationship between the variables. Therefore, with the F value of 1085.471 and highly significant F-test $(\mathrm{Sig}=0.000)$, we assume that there is a linear relationship between the variables in the model. That is, the different factors (Teacher factor (Tuition), Teacher factor (School), Socioeconomic factors, Student factor and school Leadership) simultaneously influence Students' Achievements.

Normality test. Ghozali (2006) states that the normality can be seen on the data distribution when the curve does not pass through either the left or the right. As depicted in Figure 2, it shows that the data is normally distributed. 


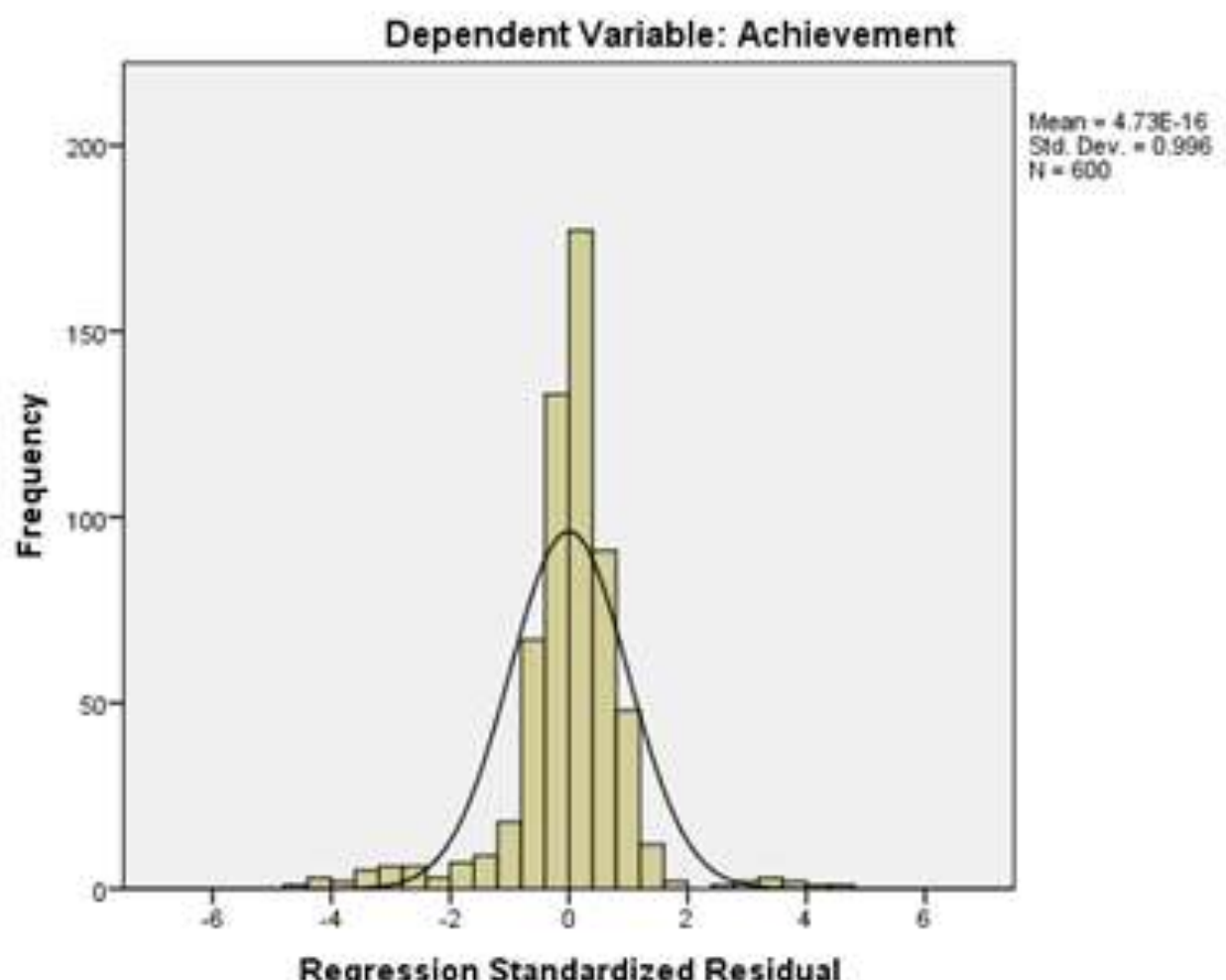

Figure 2. Normality.

Multicollinearity test. This test seeks to see whether the regression model has a correlation between independent variables. The multicollinearity is used to show the linear relationship among those variables. As depicted in table 3, it is found that the multiple regression test has no collinearity problem because the VIF values for all the independent variables shows a value lower than 10 and the values of tolerance statistics being well above 0.1 .

Homoscedasticity test. As Godfeld-Quandt test is not supported in the SPSS software, the homoscedasticity and thus normality of the residuals were checked using the Q-Q plot of the 2* Pred and 2* Presid.

The plots indicate that in our multiple linear regression model analysis, there is no tendency in the error terms and thus there is no violation of homoscedasticity.

Journal of Education and Research, Vol. 9, No. 1, 2019 
Factors Affecting Academic Achievement | 83

Autocorrelation test. Autocorrelation occurs when the residuals are not independent of each other, that is when the value of $\mathrm{Y}(\mathrm{x}+1)$ is not independent of the value of $\mathrm{Y}(\mathrm{x})$. Table 1 shows that the Durbin -Watson d is 0.940 , which is below the critical value of 1.5. Therefore, we assume that there is autocorrelation. This was inevitable as data entry was done after a visit to each school and the data collected from the students of a particular school tend to show some common features. Thus, despite little autocorrelation in data, we assume that the Multiple linear Regression model is still valid

\section{Discussion}

According to the MLRM, the factor with the greatest impacts on the students' academic achievement in the Mauritian context is school leadership. This tallies with the work of other researchers such as Leithwood et al. (2008), Robinson, Lloyd, and Rowe (2008), Swaffield and MacBeath (2009), Bush, Joubert, Kiggundu, and Van Rooyen (2010), Hallinger and Heck (2011) and Boyer (2012). However, how school leaders influence students' academic achievement vary from one context to another.

Actually, in the actual study, respondents highlighted that school leaders have major impacts on students' achievement through their roles in (i) monitoring educators role in the teaching and learning process, (ii) monitoring of student engagement in their studies, (iii) providing resources needed for quality education (iii) evaluating, monitoring and providing necessary feedback on appropriate pedagogy (iv) providing a conducive ethos and climate in the school, (v) involving parents and the immediate community in school matters, (vi) motivating students, teaching and non-teaching staffs, (vii) coaching and providing guidance and support to members of the school community and (viii) maintaining discipline.

Moreover, the participants further explained that school leaders are the head of the school and thus responsible for the school as an institution. A good school leader is someone with the ability to develop a relationship of trust with the staffs and students and thus inculcate positive working attitudes and values in the school.

The second most influential factor affecting students' achievement is the student factor. Their impacts on academic achievement have been explained by some researchers (Castillo-Merino \& Serradell-López, 2014), but the literature reveals that it varies from one context to another. Actually, the respondents explained that student 


\section{4 | S. M. C. Atchia \& V. Chinapah}

factors play a crucial role in their academic achievement in terms of time management, attitudes and behaviours. They further explained that the use/misuse of ICT tools and social media, commitment and engagement in learning, shirking of classes, intrinsic motivation and competition, boyfriend/ girlfriend affairs, stress, depression $\&$ health problems, self-esteem, CPE intake/ entry point and culture are the key components explaining the role of student factors in the academic success of any child.

The model also shows a significant positive correlation between teacher factors and students' achievement. Accordingly, Wright, Horn, and Sanders (1997) stated that if the teacher is ineffective, students under that teacher's tutelage will achieve inadequate progress academically (Wright et al., 1997). Moreover, Charles and O'Quinn (2001) stated that good teachers in subsequent grades boost achievement. Actually, analysis of the literature reveals that many researchers have identified a positive correlation between teacher factor and students' academic achievement.

In this study, the participants explained that teacher factors positively influence students' academic achievement by (i) maintaining high-quality teaching through the use of student-centred approach, (ii) ensuring teacher-students interaction and students engagement in lessons, (iii) making effective use of ICT in teaching and learning process, (iv) constantly motivating students, (v) providing necessary support, counselling and pastoral care to students, (vi) using innovative, differentiated and appropriate teaching techniques and strategies used, (vii) maintaining classroom management, (viii) ensuring proper evaluation, feedback and monitoring of students achievements, (ix) entrusting students by providing high quality and updated subject content level, (x) ensuring effective planning and organization, and (xi) maintaining discipline.

However, it was noted that the teacher factor in Tuition with a beta value of 0.154 has a higher impact on students' achievement compared to teacher factor at School with a beta value of 0.117 . The impact of tuition on learning outcomes is an area that has only received limited research attention. In a policy research report based on SACMEQ I for Mauritius (Kulpoo, 1998), tuition was found to be one of the stronger influences on pupil achievement. Yiu (1996) stated that extra tuition might have a positive outcome in improving students learning, providing students with constructive activities and enabling them to complete syllabus in time. Ireson and Rushforth (2005) viewed 
tuition as a forum to help students understand mainstream lessons. Besides, extra tuition enables learners to access extra attention, ensures improved learning styles, improved performance, personalized relationship and involvement of parents as they keep track of the performance of their children (Makworo, 2012). Maithya and Mutua (2015) concluded that most teachers $(85 \%)$ and students (82\%) supported the practice of extra tuition. It was also found that extra tuition helps students to cover the syllabus and revise for examinations. Bray (2013) stated that in an ideal world, private tuition is meant to favour individual attention, solve learning difficulties of those lagging behind and urge those aiming at excellence. However, when private tutoring starts to replace mainstream education, then problems crop up. It is then termed as the plaque or cancer of the Mauritian education system.

According to the model, the factor with the smallest impact on students' achievement is the Socio-Economic factor. The significant correlation between SEF and students' academic achievement has also been tabled by many other researchers such as Adams (1996), Kirkup (2008), and Hanes (2008). The respondents highlighted that impacts of SEF on the achievement of students is based on (i) parents' education level, (ii) family income (iii) parents role in motivating and providing guidance and support to their ward, (iii) parents involvement in the studies of their children, (iv) peer influence, (v) social networking, (vi) community and environment, (vii) seriousness in attending schools (absenteeism), (viii) cultural differences and (ix) language exposed.

However, the low impacts of SEF in the Mauritian context may be explained by the fact that Education is free at the primary, secondary and tertiary level in Mauritius. Thus, even parents with low family income manage to send their ward to school. Moreover, the parents in the focus group discussions highlighted that education of their ward is considered as a top priority in their budget as they believe that education is the only solution to all their financial problems. They firmly believe that as an educated individual, their children will be better off compared to their own realities.

\section{Conclusion}

The findings described in this paper provide crucial ground data to the different stakeholders such as policymakers and educational specialists. In addition to the identification of the contextualized factors affecting students' academic achievement in 
the Mauritian context, the study provides a reliable and significant MLRM representing the cumulative impacts of the determinants.

The MLRM provides crucial information on the degree of impacts that each factor has on student' academic achievement showing greater impacts of school leadership, following by student factor, teacher factor at tuition level, teacher factor at school level and socio-economic factor respectively. Moreover, the data captured through the focus group discussions and presented in Table 1 as the perceptions of participants provide key information on how each factor affects students' academic achievement in Mauritius. Thus, the findings presented in this paper inform policymakers, educational specialists and other stakeholders of the prioritised levels to be considered when designing relevant policies and action plans for the successful implementation of the NYCBE reform or when designing future educational reforms.

\section{ORCID}

Shakeel Mohammad Cassam Atchia (D) https://orcid.org/0000-0002-7057-6369

Vinayagum Chinapah (D) https://orcid.org/0000-0002-0586-4022

\section{References}

Adams, A. (1996). Even basic needs of young are not met. Retrieved from http $/ /$ tc.education.pitt.edu/library/SelfEsteem

Allen, N., Grigsby, B., \& Peters, M. (2015). Does leadership matter? Examining the relationship among transformational leadership, school climate, and student achievement. International Journal of Educational Leadership Preparation, 10(2), 1-22. Retrieved from https://files.eric.ed.gov/fulltext/EJ1083099.pdf

Beare, H., Caldwell, B. J., \& Millikan, R. H. (2018). Creating an excellent school. London, England: Routledge.

Benner, A. D., Boyle, A. E., \& Sadler, S. (2016). Parental involvement and adolescents' educational success: The roles of prior achievement and socioeconomic status. Journal of Youth Adolescence, 45, 1053-1064.

https://doi.org/10.1007/s10964-016-0431-4

Berkowitz, R., Moore, H., Avi Astor, R., \& Benbenishty, R. (2017). A research synthesis of the associations between socioeconomic background, inequality, school climate, and academic achievement. Review of Educational Research, 87(2), 425469. https://doi.org/10.3102/0034654316669821

Journal of Education and Research, Vol. 9, No. 1, 2019 
Factors Affecting Academic Achievement | 87

Boyer, D. P. (2012). A study of the relationship between the servant leader principal on school culture and student achievement in the Lower Kuskokwim school district. Arizona, AZ: Grand Canyon University.

Bray, M. (2010). Blurring boundaries: The growing visibility, evolving forms and complex implications of private supplementary tutoring. Orbis Scholae, 4(2), 61-73 Bray, M. (2009). Confronting the shadow education system: What government policies for what private tutoring? Paris, France: UNESCO International Institute for Educational Planning (IIEP).

Bray, M. (2013). Benefits and tensions of shadow education: Comparative perspectives on the roles and impact of private supplementary tutoring in the lives of Hong Kong students. Journal of International and Comparative Education, 2(1), 18-30.

Bush, T., Joubert, R., Kiggundu, E., \& Van Rooyen. J. (2010). Managing teaching and learning in South African schools. International Journal of Educational Development, 30(2), 162-168. https://doi.org/10.1016/j.ijedudev.2009.04.008

Capra, F. (1996). The web of life: A new scientific understanding of living systems. New York, NY: Anchor Books.

Carr, A. (2006). Family therapy: Concepts, process and practice (2nd ed.). West Sussex, England: John Wiley \& Sons.

Castillo-Merino, D., \& Serradell-López, E., (2014). An analysis of the determinants of students' performance in e-learning. Computers in Human Behavior, 30, 476-484.

Charles, T., \& O'Quinn, S. (2001). Eliminating the black-white achievement gap: A summary of research. Chapel Hill, NC: North Carolina Education Research Council.

Chikere, C. C., \& Nwoka, J. (2015). The systems theory of management in modern-day organizations - A study of Aldgate Congress Resort Limited Port Harcourt.

International Journal of Scientific and Research Publications, 5(9).

Day, C., Gu, Q., \& Sammons, P. (2016). The impact of leadership on student outcomes: How successful school leaders use transformational and instructional strategies to make a difference. Educational Administration, 52(2), 221- 258.

Ghozali, I. (Ed.). (2006). Analisis Multivariate Lanjutan Dengan Program SPSS. Hair, N. L., Hanson, J. L., Wolfe, B. L., \& Pollak, S. D. (2015). Association of child poverty, brain development, and academic achievement. JAMA Pediatric, 169, 822-29.

Hallinger, P., \& Heck, R. H. (2011). Exploring the journey of school improvement: Classifying and analyzing patterns of change in school improvement processes and 
88 | S. M. C. Atchia \& V. Chinapah

learning outcomes. School Effectiveness and School Improvement, 22(1), 1-27. https://doi.org/10.1080/09243453.2010.536322

Han, S. Y., Capraro, R. M., \& Capraro, M. M. (2015). How science, technology, engineering, and mathematics (STEM) project-based learning (PBL) affects high, middle, and low achievers differently: The impact of student factors on achievement. International Journal of Science and Mathematics Education. https://doi.org/10.1007/s10763- 014-9526-0

Hanes, B. (2008). The exploration of socioeconomic status and student achievement at Beverly elementary school. Ohio, OH: Marietta College.

Hitt, D. H., \& Tucker, P. D. (2016). Systematic review of key leader practices found to influence student achievement: A unified framework. Review of Educational Research, 86, 531-569.

Ireson, J., \& Ruashforth, K. (2005). Mapping and evaluating shadow of education (ESRC Research project RES-000-23-0117). London, England: Institute of Education, and the University of London.

Kang, J., \& Keinonen, T. (2018). The effect of student-centred approaches on students' interest and achievement in science: Relevant topic-based, open and guided inquirybased and discussion-based approaches. Research in Science Education, 48(4), 865885

Kirkup, J. (2008). Middle-class children resentful at being pushed to succeed. Retrieved from http:/www.telegraph.co.uk/education/3330301/Middleclass- childrenresentful-at-being-pushed-to-succeedpoll-shows.html

Konstantopoulos, S. (2009). Effects of teachers on minority and disadvantaged students' achievement in the early grades. The Elementary School Journal, 110, 92-113. https://doi.org/10.1086/598845

Kulpoo, D. (1998). The quality of education: Some policy suggestions based on a survey of schools (SACMEQ Policy Research Report No. 1). Paris, France: UNESCO/IIEP.

Leithwood, K., Harris, A., \& Hopkins. D. (2008). Seven strong claims about successful school leadership. School Leadership \& Management, 28(1), 27-42.

https://doi.org/10.1080/13632430701800060

Lemberger, M., E., Selig, J. P., Bowers, H., \& Rogers, J. E. (2015). Effects of the student success skills program on executive functioning skills, feelings of connectedness, and academic achievement in a predominantly Hispanic, low-income middle school district. Journal of Counselling Development, 93(1), 25-37.

Journal of Education and Research, Vol. 9, No. 1, 2019 
Factors Affecting Academic Achievement $\mid 89$

Lubienski, S. T. (2002). A closer look at Black-White mathematics gaps: Intersections of race and SES in NAEP achievement and instructional practices data. The Journal of Negro Education, 71(4), 269-287.

Ma, X., \& Klinger, D. A. (2000). Hierarchical linear modeling of student and school effects on academic achievement. Canadian Journal of Education, 25(1), 41-55.

Maithya, R., \& Mutua, E. K. (2015). Teachers and students' perception on effect of extra tuition on academic performance in public secondary schools in Machakos County, Kenya. Journal of Educational Policy and Entrepreneurial Research, 2(8), 57-66.

Makworo, G. W. (2012). How can teachers teach effectively without extra tuition? Unpublished manuscript.

Mirowsky, J. (2017). Education, social status and health. New York, NY: Routledge.

Mulford, B., Edmunds, B., Ewington, J., Kendall, L., Kendall, D., \& Silins, H. (2009). Successful school principalship in late career. Journal of Educational Administration, 47(1), 36-49.

Mushtaq, I., \& Khan, S. N. (2012). Factors affecting students' academic performance. Journal of Management and Business Research, 12(9), 16-22.

Pedrosa, R. H. L., Dachs, J. N. W., Maia, R. P., \& Andrade, C. Y. (2006). Educational and social-economic background of graduates and academic performance:

Consequences for affirmative action programs at a Brazilian research university.

Retrieved from http://www.comvest.unicamp.br/paals/artigo2.pdf

Pont, B., Nusche, D., \& Moorman, H. (2008). Improving school leadership. Policy and practice. Paris, France: OECD.

Robinson, V. M. J., Lloyd, C. A., \& Rowe, K. J. (2008). The impact of leadership on student outcomes: An analysis of the differential effects of leadership types. Educational Administration, 44(5), 635-674. https://doi.org/10.1177/0013161X08321509

Shores, M. L., Shannon, D. M., \& Smith, T. G. (2010). Individual learner variables and their effect on mathematics achievement as students advance from fifth to sixth grade. Journal of Research in Childhood Education, 24(3), 187-194.

Supovitz, J., Sirinides, P., \& May, H. (2009). How principals and peers influence teaching and learning. Educational Administration Quarterly, 46(1), 36-56. 
$90 \mid$ S. M. C. Atchia \& V. Chinapah

Swaffield, S., \& MacBeath. J. (2009). Researching leadership for learning across international and methodological boundaries. Retrieved from http $/ /$ www.educ.cam.ac.uk/ centres/lfl/about/swaffieldmacbeath\%20aera09.pdf Tate, W. F. (1997). Race-ethnicity, SES, gender, and language proficiency trends in mathematics achievement: An update. Journal for Research in Mathematics Education, 28, 652-679.

Vizeshfar, F., \& Torabizadeh, C. (2018). The effect of teaching based on dominant learning style on nursing students' academic achievement. Nurse Education in Practice, 28, 103-108.

Von Bertalanffy, L. (1956). General systems theory. General Systems, 1, 1-10

Wright, S. P., Horn, S. P., \& Sanders, W. L. (1997). Teacher and classroom context effects on student achievement: Implications for teacher evaluation. Journal of Personnel Evaluation in Education, 11, 57-67.

Yaşar, M. (2017). Adaptation of general system theory and structural family therapy approach to classroom management in early childhood education. Cukurova University Faculty of Education Journal, 46, 665-696.

Yiu, J. M. (1996). A study of curriculum change in Hong Kong: The case of advanced level of economics. Hong Kong: The University of Hong Kong.

\section{To cite this article:}

Atchia, S. M. C., \& Chinapah, V. (2019). Factors affecting the academic achievement of secondary school students in Mauritius. Journal of Education and Research, 9(1), 70-90. https://doi.org/10.3126/jer.v9i1.28825

Journal of Education and Research, Vol. 9, No. 1, 2019 